This study has established patterns in the plasmochemical activation of technological solutions in the process of malt production. Of importance is the application of innovative technologies to purify water and technological solutions used at malt enterprises that consume large quantities of water resources. A promising technology is the plasmochemical treatment of water and technological solutions in order to purify them and, partially or completely, destroy pathogenic microflora. Due to the use of plasmochemical activation, it has become possible not only to improve the malting process but also to reduce the consumption of water resources for technological purposes by 2-3 times. This is achieved by improving the technological malting process and by the possibility of reuse of wastewater after its filtering and plasmochemical treatment. The experimental laboratory tests have proven the effectiveness of using plasmochemical activation of technological solutions in order to improve the qualitative indicators of wastewater and the possibility of reuse of such solutions after their plasmochemical activation. Applying the proposed method for treating technological solutions decreased the level of contamination of wastewater from malt production. Sewage contamination after activation decreased. Thus, pollution indicators decreased as follows: per dry residue - by 65-95\%; the content of suspended substances - by 33-66\%; residue after roasting - by 58-79 \%; total nitrogen - by $58-80 \% ; \mathrm{P}_{2} \mathrm{O}_{5}$ (phosphorus) - by 75-88\%; $\mathrm{K}_{2} \mathrm{O}$ (potassium) - by 75-92 \%; CaO (calcium) by 81-92 \%; $\mathrm{Na}_{2} \mathrm{O}-$ by $67-83 \% ; \mathrm{Cl}^{-}-$not detected; oxidation - by 78-95\%; $\mathrm{BOC}_{5}$ (biochemical oxygen consumption) - by 92-97\%; pH became alkaline. In plasmochemical treatment, there is a disinfection of wastewater, namely, during an activation mode of $60 \mathrm{~min}$ the phytopathogenic microflora (Aspergillus, Alternaria, Penicillium, Fusarium, Mucor) were destroyed. This indicates the effectiveness of the purification and decontamination of technological solutions. Its application is the key to the environmental safety of malt production when all its stages meet the requirements of "green" technologies

Keywords: malt production, plasmochemical activation, technological solutions, ecologization, wastewater
UDC 663.43: 663.63

DOI: $10.15587 / 1729-4061.2020 .215160$

\section{IMPLEMENTATION OF THE PLASMOCHEMICAL ACTIVATION OF TECHNOLOGICAL SOLUTIONS IN THE PROCESS OF ECOLOGIZATION OF MALT PRODUCTION}

\author{
O. Kovaliova \\ $\mathrm{PhD}$, Associate Professor* \\ O. Pivovarov \\ Doctor of Technical Sciences, Professor* \\ V. Kaly n a \\ $\mathrm{PhD}$, Associate Professor* \\ E-mail: viktoriya-kalina@ukr.net \\ Y u. T c hoursinov
}

Doctor of Technical Sciences, Professor, Academician of the Academy of Engineering Sciences of Ukraine, Head of Department*

E. Kun itsia

$\mathrm{PhD}$

Department of Innovative Food and Restaurant Technologies Kharkiv Institute of Trade and Economics of Kyiv National University of

Trade and Economics

O. Yarosha lane, 8, Kharkiv, Ukraine, 61045

A. Cher n u k h a

$\mathrm{PhD}$ **

D. Polkovn y chenko $\mathrm{PhD**}$

N. Grigorenko $\mathrm{PhD}$

Department of Management and Organization in the Field of Civil Protection***

T. Kurska

PhD, Associate Professor Department of Fire Prevention in Settlements***

O. Yermakova

$\mathrm{PhD}$, Associate Professor

Department of Engineering and Computer-Generated Graphics Kharkiv National Automobile and Highway University Yaroslava Mudroho str., 25, Kharkiv, Ukraine, 61002

*Department of Technology of Storage and Processing of Agricultural Products

Dnipro State Agrarian and Economic University Serhiya Yefremova str., 25, Dnipro, Ukraine, 49600

**Department of Fire Rescue Training***

$* * *$ National University of Civil Defence of Ukraine

Chernyshevska str., 94, Kharkiv, Ukraine, 61023

Copyright (C) 2020, O. Kovaliova, O. Pivovarov, V. Kalyna, Yu. Tchoursinov, E. Kunitsia, A. Chernukha, D. Polkovnychenko, N. Grigorenko, T. Kurska, O. Yermakova This is an open access article under the CC BY license (http://creativecommons.org/licenses/by/4.0)
1. Introduction

Environmental aspects of food and processing production are the key to a high standard of living for people and mental situation can be characterized as a crisis [1]. The imperfect structure of industrial production for many decades was formed without taking into consideration the objective 
needs of the population and economic opportunities for producers. For a long time, there were structural changes in production facilities, when the preference was given to the development of raw materials and extraction, the most environmentally hazardous industries around the world. Developing countries have a high share of resource- and energy-intensive technologies, the introduction, and buildup of which was carried out in the "cheapest" way - without the construction of treatment facilities. This also applies to food production [2].

It should be noted that most food companies operate morally obsolete and physically worn environmental equipment (for example, water treatment facilities), sometimes it is absent, waste recycling technologies are not employed, etc. [1]. This leads to emissions of large amounts of pollutants (toxic substances) into the environment, much of which are hazardous due to the infiltration of various, sometimes very toxic components into groundwater and surface waters.

Industrial production of food products is mostly characterized by high specific costs of raw materials, fuel, energy, water, and other natural resources, which makes it uncompetitive in the international market. Constant emissions of food production waste in the biosphere led to its significant contamination, which was in the way of the production of environmentally friendly food raw materials for processing enterprises. There is no systematic qualitative monitoring of the ecological status by the regulatory authorities, which significantly worsens the existing situation.

The modern development of the malt industry shows that the issues of production, consumption, and quality of products are connected with the issue of environmental friendliness of production, as well as the environmental safety of products. In addition, the use of chemical intensifiers in the malting process, as a rule, significantly worsens the state of technological solutions (sewage water). Thus, the application of organic acids [3], including fruit [4], significantly reduces the $\mathrm{pH}$ and cause the acidifying of wastewater and reservoirs which they penetrate.

It should be noted that many food companies generally ignore the need to purify wastewater, which leads to irreversible processes in the ecosystem.

The issue of the introduction of innovative technologies for sewage treatment of malt enterprises [5] is acute. Most often, the production is limited to wastewater filtration and alkalization [6], which does not solve the problem of high-quality treatment of technological solutions and the possibility of its reuse in technological processes [7].

The urgency of finding the latest methods of wastewater treatment lies in the need to improve the ecological state of the food industry, as pollution of water resources by the food processing industry takes on a critical scale [8]. Thus, the indicators of sewage contamination may amount to: dry residue $-2,300 \mathrm{mg} / \mathrm{dm}^{3}$; suspended substances $-850 \mathrm{mg} / \mathrm{dm}^{3}$; residue after roasting $-240 \mathrm{mg} / \mathrm{dm}^{3}$; total nitrogen $270 \mathrm{mg} / \mathrm{dm}^{3}$; phosphorus - $150 \mathrm{mg} / \mathrm{dm}^{3}$; potassium $64 \mathrm{mg} / \mathrm{dm}^{3}$; calcium - $134 \mathrm{mg} / \mathrm{dm}^{3}$; sodium $-3 \mathrm{mg} / \mathrm{dm}^{3}$; oxidation - $960 \mathrm{mg} \mathrm{O}_{2} / \mathrm{dm}^{3}$; biochemical oxygen consumption $-1,800 \mathrm{mg} \mathrm{O}_{2} / \mathrm{dm}^{3} ; \mathrm{pH}$ 6.0. Such values indicate a high level of wastewater contamination and outdated methods and equipment for its purification. In other words, the available wastewater treatment technologies do not provide a sufficient level of purification. The lack of improvement of wastewater treatment technology at malt enterprises may adversely affect the overall state of bioresources [9]. In addition, it is important to obtain environmentally friendly food products [10]. Therefore, the introduction of innovative water purification methods, which include plasmochemical activation, is a priority area of technological developments.

\section{Literature review and problem statement}

Papers [1,2] report the results of studying the ecological state of the food industry, namely, the malting process. It is shown that high-quality environmentally friendly raw materials and highly efficient innovative technologies are needed for the production of environmentally friendly and safe food products. However, there remains an unresolved issue related to the compliance with the high level of environmental safety of production. The option of overcoming this problem is to bring the technological processes of malt production to the requirements of "green" technologies. And the products themselves (a variety of malts) should have a "green" mark, which must indicate their high quality and environmental safety.

The food industry consumes mainly drinking water [11], which is cleaned at the city's water treatment plants, sometimes at the enterprises themselves. It is shown that most water treatment facilities use water purification technologies that are more than two decades old, it becomes clear that they do not ensure that water of proper quality is obtained. It is especially true regarding the content of soluble impurities (nitrates, pesticides, heavy metals, chlorides, sulfates, etc.) since their treatment is not implied by generally accepted technology. All this allows us to argue that the manufacture of food products mainly involves water of unsatisfactory quality, which may not only reduce the quality of products but also adversely affect the health of consumers. Therefore, the option of overcoming such difficulties is the introduction of innovative water treatment technologies.

Each technology of food production has its own characteristics [6], and contamination of water resources is characterized by the composition of raw materials processed at an enterprise. It is shown that due to the use of large amounts of water in food production technology, a large amount of contaminated wastewater is accumulated. Features of sewage composition correspond to the specificity of the company that dumps them. Work [11] gives a composition of wastewater formed at malt enterprises (Table 1). The reason for the significant contamination of water is that the treatment facilities at malt industry enterprises are quite rare, so innovative water purification technologies are of increased interest to producers. The option of overcoming difficulties is a special demand for high-tech methods of water purification, which make it possible to use technological solutions in a closed production cycle, which significantly reduces the cost of finished products and makes it possible to reduce the consumption of natural resources, especially drinking water.

Table 1 shows that wastewater [11] is contaminated mainly with organic impurities, which are remnants of the raw materials and products of its transformation. The reason for this is that wastewater and other waste are now mainly stored in the territory of factories, or dumped into nearby reservoirs. This leads to contamination of groundwater, soils, and atmospheric air. At many enterprises, wastewater containing soluble and hard-to-soluble organic compounds is dumped into the city's sewerage network from which they penetrate urban sewage treatment plants. The latter, due to the imperfection 
of technology, mostly operate unsatisfactorily. Therefore, insufficiently treated wastewater can enter natural reservoirs and cause great damage to both natural ecosystems and people themselves. The option of overcoming the appropriate difficulties is to provide food production with high-quality water; it should be additionally cleaned at the enterprises and spent economically. This involves the use of lean technologies for washing raw materials, equipment, tares, the organization of closed water cycles, in which water after cleaning and cooling could be used again for technological processes of food production. At big malt enterprises, where a large amount of wastewater is formed, it is necessary to organize local purification using innovative methods. Wastewater pollutants are mostly organic matter. With the help of microorganisms in biotechnological processes, they can be transformed into protein, vitamin, and other products. It is possible to use them subsequently in other sectors, for example, in agriculture [7]. This approach makes it possible to partially solve the issue of water resource contamination. However, still, it is desirable to look for a comprehensive approach to the problem of the ecological status of enterprises.

Table 1

Wastewater composition at breweries and malt plants [11]

\begin{tabular}{|c|c|}
\hline Indicator & Quantity \\
\hline Dry residue & $250-2.300 \mathrm{mg} / \mathrm{dm}^{3}$ \\
\hline Suspended substances & $30-850 \mathrm{mg} / \mathrm{dm}^{3}$ \\
\hline Residue after roasting & $240 \mathrm{mg} / \mathrm{dm}^{3}$ \\
\hline Overall nitrogen & $150-270 \mathrm{mg} / \mathrm{dm}^{3}$ \\
\hline $\mathrm{P}_{2} \mathrm{O}_{5}$ (phosphorus) & $30-150 \mathrm{mg} / \mathrm{dm}^{3}$ \\
\hline $\mathrm{K}_{2} \mathrm{O}$ (potassium) & $40-64 \mathrm{mg} / \mathrm{dm}^{3}$ \\
\hline $\mathrm{CaO}$ (calcium) & $90-134 \mathrm{mg} / \mathrm{dm}^{3}$ \\
\hline $\mathrm{Na}_{2} \mathrm{O}$ & $3 \mathrm{mg} / \mathrm{dm}^{3}$ \\
\hline $\mathrm{Cl}$ & - \\
\hline $\mathrm{Oxidation}^{-}$ & $150-960 \mathrm{mg} \mathrm{O}{ }_{2} / \mathrm{dm}^{3}$ \\
\hline $\begin{array}{c}\mathrm{BOC} \\
\text { oxygen consumption) }\end{array}$ & $300-1,800 \mathrm{mg} \mathrm{O} \mathrm{O}_{2} / \mathrm{dm}^{3}$ \\
\hline $\mathrm{pH}$ & $6.0-7.2$ \\
\hline (biochemical &
\end{tabular}

Work [11] states that in the production of malt the main amount of water is spent on soaking and washing grain. Water after soaking has in its composition extractive substances and calcium compounds. And, together with the washing water, it would have total contamination of up to $2,000 \mathrm{mg} \mathrm{O}_{2} / \mathrm{l}$ in terms of HSC (chemical oxygen consumption). The sewerage network is allowed to receive wastewater with a COC of 200-300 $\mathrm{mg} \mathrm{O}_{2} / \mathrm{l}$. Non-treated wastewater is able to rot; during this process the microorganisms produce lactic, oil, and acetic acids, causing corrosion of the sewerage network and inhibiting the process of biological treatment of wastewater. Enterprises practice its alkalization. Total water consumption in production ranges from 3 to $10 \mathrm{~m}^{3}$ per $1 \mathrm{t}$ of barley $[2,11]$. It is this issue that requires urgent resolution because such a high level of water use can significantly worsen the state of the ecosystem.

Activating water and aqueous solutions through plasmochemical treatment is the first step to using water properties without the participation of artificial foreign chemicals of various origin [13]. The resulting activated water has a spe- cific composition. The most easily defined are the products of reaction that determine its reactivity. First, it concerns hydrogen peroxide and ultra-peroxide compounds, excited particles, and radicals that play an important role in oxidative-reducing processes.

Thus, all processes that occur during activation are processes that take place directly in the aquatic environment [12]. The reactogenic properties of the plasmochemically treated water are of increased interest to scientists as the properties of water that emerge after activation can be a starting point in the development of a new direction of nanotechnology [13]. Plasmochemically activated aqueous solutions demonstrate antiseptic and antibacterial properties [14]. Such water after plasma treatment is a cluster structure and can exhibit some new properties, previously little studied, but which are of interest from a practical point of view $[15,16]$. The study of technological processes of wastewater treatment of food production is given a special role in this case [17]. One of these processes is the plasmochemical treatment of malt production wastewater in order to purify and decontaminate it.

Water is the base of technological solutions and is directly the main factor in the malt production process. Activating technological aqueous solutions by plasmochemical treatment is the first step to using the properties of water without its forced chemicalization by foreign chemicals.

All the processes that occur during activation proceed directly in the aqueous solution without the addition of foreign chemical components. The water, activated under the action of contact nonequilibrium plasma, has antiseptic and antibacterial properties [18]. The reactogenic properties of activated water are of increased interest to scientists as the properties of water that emerge after activation can be a starting point in the development of a new direction of nanotechnology.

In addition to a change in the chemical composition of water, it was determined that the parameters of water (cluster structure) change when it is exposed to different physical types of influence on it. The cluster water structure has been addressed in many works [19]. The first models of water began to occur at the end of the XIX century when many actual data about its anomalies accumulated [20]. The idea of numerous short-lived hydrogen bonds between neighboring hydrogen and oxygen atoms in the water molecule is of particular importance [21]. They can form, in case of favorable conditions, special structures - the associates of water molecules (clusters) [22].

In the cluster model, water is considered to be a mixture of individual clusters connected by hydrogen bonds of water molecules that "float" among free unrelated water molecules [18]. This cluster water model appears most attractive to many researchers [20]. It is due to the presence of such connections that in certain micro-volumes of water there continuously occur structural elements - the clusters of water. The emergence and disintegration of clusters can be expressed by the scheme: $x \cdot \mathrm{H}_{2} \mathrm{O} \leftrightarrow\left(\mathrm{H}_{2} \mathrm{O}\right)_{x}$. The relative stability of clusters depends on external factors: exposure to electromagnetic fields, temperature, etc. In a given case, such an external factor is the contact effect of an uneven low-temperature plasma on the surface layer of water [22]. This effect disrupts the formed stable dynamic balance in ordinary water and leads to partial or almost complete destruction of clusters. At the same time, an additional number of free unbound water molecules is formed [18]. Further reactogenicity may have a specific effect on chemical components present in treated solutions. 
Theoretical and applied research in this area is conducted in Ukraine [16, 17]. However, these works did not pay attention to the processes of wastewater treatment in food production.

The issue of effective development of food and processing enterprises remains unresolved, and this is impossible without solving a set of ecological and economic problems. In order to overcome the acute environmental crisis, it is necessary to ecologize the food and processing industry. One of the ways towards the ecologization of malt industry is the high-quality treatment and disinfection of malt production wastewater using innovative techniques and methods of purification.

It can be argued that it is advisable to conduct research into the use of plasmochemical activation of technological solutions in order to purify them. This approach was highlighted in study [12]; the activation of aqueous solutions is represented as an environmental technology with a wide scope of application.

\section{The aim and objectives of the study}

The aim of this study is to establish the modes and effectiveness of using the plasmochemical activation of technological solutions (wastewater) in the malting process for their purification and disinfection.

To achieve the set aim, the following tasks have been solved:

- the plasmochemical treatment of technological solutions (wastewater) generated from malt production, to determine the degree of their chemical and microbiological purification depending on the treatment duration;

- studying the composition of malt production wastewater based on the following indicators: dry residue; suspended substances; residue after roasting; total nitrogen; $\mathrm{P}_{2} \mathrm{O}_{5}$ (phosphorus); $\mathrm{K}_{2} \mathrm{O}$ (potassium); $\mathrm{CaO}$ (calcium); $\mathrm{Na}_{2} \mathrm{O}$; $\mathrm{Cl}^{-}$; oxidation; $\mathrm{BOC}_{5}$ (biochemical oxygen consumption); $\mathrm{pH}$ under different modes of plasmochemical treatment;

- investigating the effect of plasmochemical treatment on the phytopathogenic microflora of wastewater.

\section{Materials and methods to study the use of plasmochemical activation of wastewater in the process of malting process ecologization}

4.1. Examined materials and equipment used in the experiment. The plasmochemical activation of technological solutions

The plasmochemical activation of technological solutions was carried out using a laboratory plasmochemical installation (Fig. 1).

The installation operates as follows: the input voltage is fed to the boosting transformer. Next, from the secondary winding of the transformer, an alternating voltage is fed to the bridge straightener; the pulsating direct voltage is fed through a ballast resistor to the reactor's electrodes. The reactor's anode is connected to an ignition device that generates pulses with an amplitude of up to $15 \mathrm{kV}$ at a duration of up to $1.5 \mathrm{~ms}$. The pulses are strictly synchronized with the pulsating voltage phase. At the time of generating an ignition pulse, there is a breakdown of the vacuum space (created by pumping the gas phase from the reactor with a vacuum pump) between the reactor's electrodes. There is a sharp decline in resistance, resulting in the flow of anode current, creating a discharge. The discharge combustion voltage is almost invariable at $750-900 \mathrm{~V}$ and depends on the degree of gas rarefaction inside the reactor. The current of the discharge gap is predetermined by the plasma resistance and the amount of voltage applied to the system; a plasma discharge is a ballast regulator. The voltage value is adjusted according to the phase method, that is, the average anode voltage value, fed to the reactor, depends on the pulsating voltage phase on the anode and the moment the pulse is ignited. Plasma occurs at the time of ignition and extinguishes at the time of the end of the pulses of anode voltage. The recurrence rate of the process is $100 \mathrm{~Hz}$. The discharge current adjustment used in the device is carried out by changing the moment of ignition with respect to the pulsation phase of the anode voltage using a synchronizing device. The power control device in this case is the reactor itself. Plasma discharge parameters are registered using devices of type M4200, class 4.0. Specifications of the reactor and the basic operational parameters of the laboratory installation are given in Tables 2, 3 .

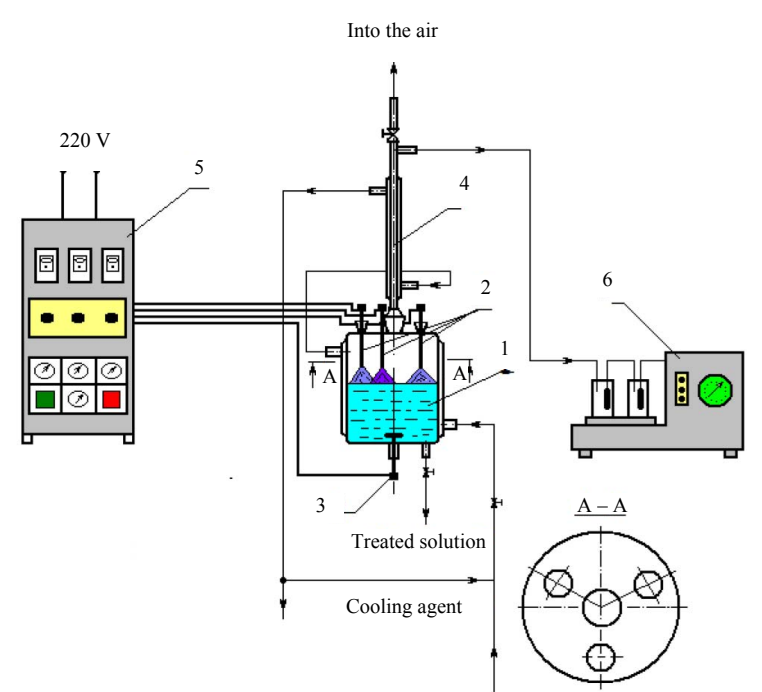

Fig. 1. Laboratory installation for the plasmochemical treatment of water and aqueous solutions: 1 - reactor; 2 - anodes; 3 - cathode; 4 - reverse refrigerator; 5 - power supply; 6 - vacuum pump

Table 2

Reactor specifications

\begin{tabular}{|c|c|}
\hline Reactor volume & $4 \times 10^{-5} \mathrm{~m}^{3}$ \\
\hline Diameter & $3,4 \times 10^{-2} \mathrm{~m}$ \\
\hline Height & $0.2 \mathrm{~m}$ \\
\hline Material & Molybdenum glass \\
\hline Electrode & Stainless steel \\
\hline Movable electrode & Refractory material \\
\hline
\end{tabular}

Table 3

Operational parameters of the laboratory installation

\begin{tabular}{|c|c|c|}
\hline Parameter & Power supply & Quantity \\
\hline Input voltage & Alternating one-phase & $\sim 50 \mathrm{~Hz}-220 \mathrm{~V}$ \\
\hline Output voltage & $\begin{array}{c}\text { Direct, pulsating, } \\
\text { adjusted in the range }\end{array}$ & $700-1,500 \mathrm{~V}$ \\
\hline Load current & Maximal value & $0.3 \mathrm{~A}$ \\
\hline Ignition load & $\begin{array}{c}\text { Amplitude } \\
\text { Pulse duration }\end{array}$ & $\begin{array}{c}12,000-15,000 \mathrm{~V} \\
1.0-1.5 \mathrm{~ms}\end{array}$ \\
\hline
\end{tabular}


4. 2. Procedure for determining the composition of wastewater from malt production

We studied wastewater composition by using standard procedures to determine the indicators of wastewater contamination. Thus, the dry residue and the residue after roasting were determined by moisture evaporation according to MVV 081/12-0109-03. The suspended substances in solutions were registered by a gravimetric method according to the procedure KND 211.1.4.039-95. The total nitrogen and the $\mathrm{P}_{2} \mathrm{O}_{5}$ phosphorus content were determined by a photometric method (photocolorimeter KFK-2). We determined the content of sodium, potassium, calcium by using a flame-photometric method (the flame photometer CL-378, India). The presence of chlorine in the solutions was determined by argentometric titration. $\mathrm{BOC}_{5}$ (biochemical oxygen consumption) was determined by the estimation method, by determining the solution of oxygen in the corresponding diluted test sample under standard conditions (MBB methodology 081/12-0014-01). The acidity of solutions $(\mathrm{pH})$ was determined by using a colorimetric method and a potentiometry method at the device pH-150 (Ukraine).

Microbiological examination of wastewater was carried out by seeding it on nourishing environments and by registering existing microorganisms using a biological microscope (XS-5520 LED MICROmed, China).

\section{Results of studying the chemical and microbiological composition of malt production wastewater after plasmochemical activation}

The plasmochemical activation of technological solutions was used at the stage of treating malt production wastewater for the purpose of their reuse. We examined the composition of malt production wastewater using the plasmochemical activation of technological solutions. Sampling of wastewater was carried out at the specialized enterprise. Various parameters of solution activation were used, namely, wastewater treatment time in a plasmochemical reactor (10-60 min.). The activation was carried out in a plasma-chemical reactor at the specialized laboratory, DVNZ "Ukrainian State Chemical and Technological University” (Ukraine).

5. 1. Studying dry residue and suspended substances in wastewater

We examined the dry residue, found in malt production wastewater, before and after plasmochemical activation. After the first 10 minutes of activation, the measurements were carried out every 5 minutes. The dynamics of changes in the indicator are shown in Fig. 2.

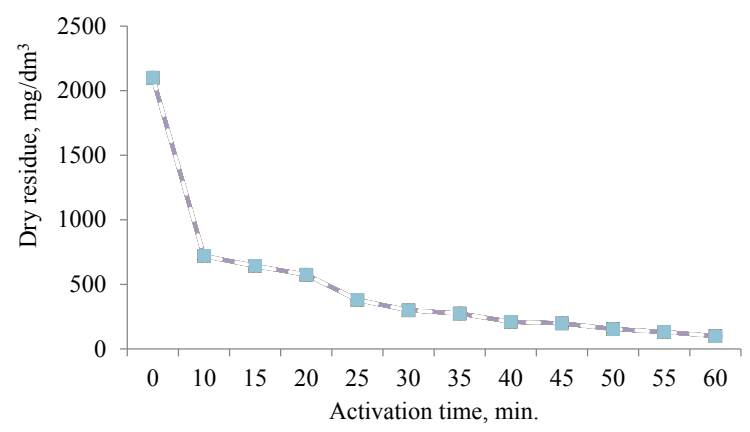

Fig. 2. Dry residue in malt production wastewater when using the plasmochemical activation of technological solutions
The results that are shown in Fig. 2 indicate a decrease in the amount of dry residue in solutions when using plasmochemical activation. Increased activation time contributed to better wastewater treatment.

The analysis of the results was also carried out. The linear equation of regression is shown in Fig. 3.

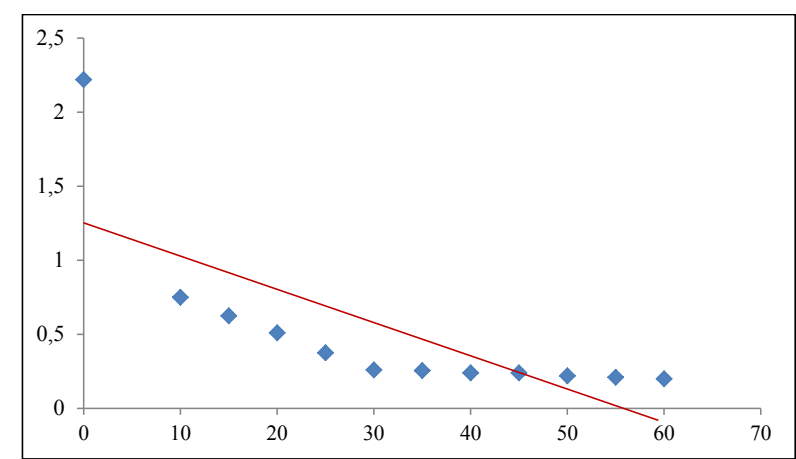

Fig. 3. Chart of the regression equation for a change in dry residue in the composition of wastewater $(\hat{y}=-23.4695 x+1235.3964)$

Fisher's criterion was $F_{\text {fakt }} \approx 17.9015, F_{\text {tabl }} \approx 4.9646, \alpha=0.05$; Student's $t$-statistics $t_{\text {tabl }} \approx 2.2282, t_{a} \approx-4.231, \alpha=0.05$. Darbin-Watson criterion was $d \approx 1.1474$.

The amount of suspended substances in wastewater was investigated, the change in this indicator is shown in Fig. 4.

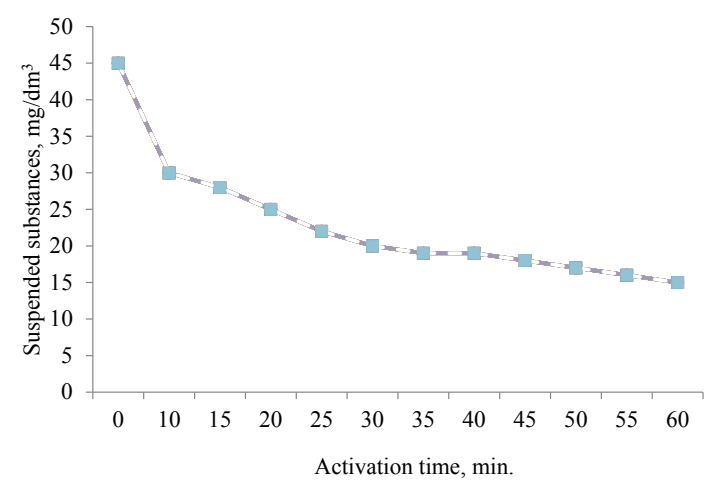

$a$

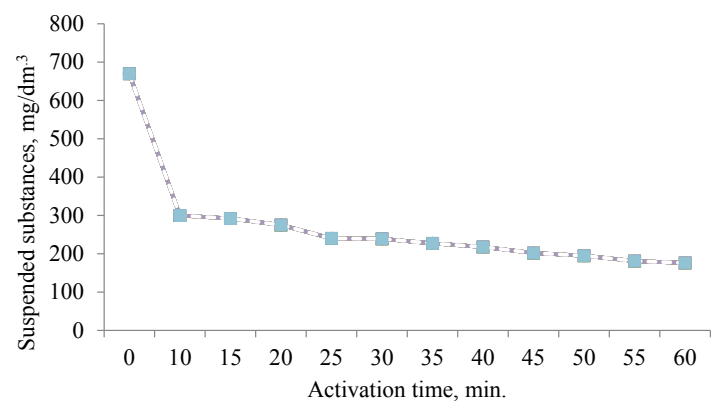

$b$

Fig. 4. Suspended substances in the composition of malt production wastewater when using the plasmochemical activation of technological solutions: $a$ - filtration; $b-$ no filtration

The results that are shown in Fig. 4 indicate a decrease in the number of suspended substances in solutions when using plasmochemical activation. This is especially effective after the filtering of wastewater. The dynamics of reducing 
the amount of suspended substances while increasing activation time persists. The analysis of the results was carried out. The linear regression equation is shown in Fig. 5.

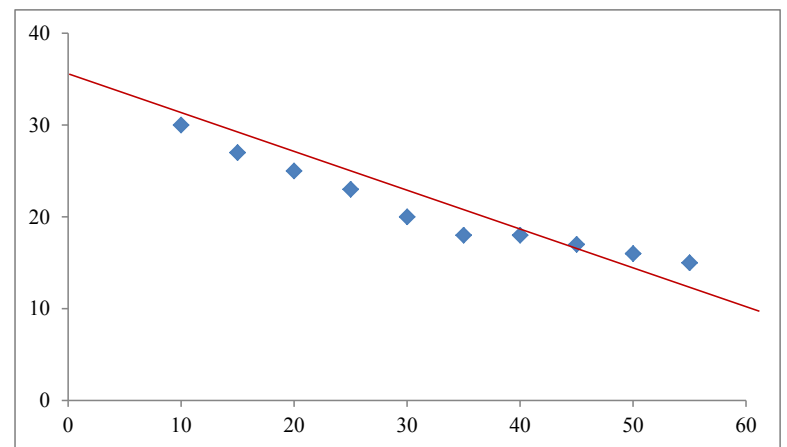

Fig. 5. Chart of the regression equation for a change in the amount of suspended substances in the composition of wastewater $(\hat{y}=-0.4017 x+35.7219)$

Fisher's criterion was $F_{\text {fakt }} \approx 40.9427 ; F_{\text {tabl }} \approx 4.9646, \alpha=$ $=0.05$; Student's $t$-statistics $t_{\text {tab }} \approx 2.2282, t_{a} \approx-6.3986, \alpha=0.05$. The Darbin-Watson criterion was $d \approx 0.8628$.

The dry residue after roasting was also investigated. The data obtained are shown in Fig. 6.

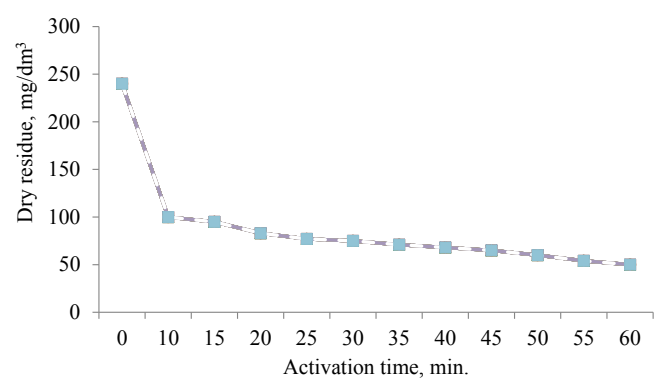

Fig. 6. Dry residue after roasting in the composition of malt production wastewater when using the plasmochemical activation of technological solutions

Analyzing the obtained data, it is necessary to note the similar dynamics to the reduction of dry residue after roasting in wastewater. The results allowed us to build a linear regression equation shown in Fig. 7.

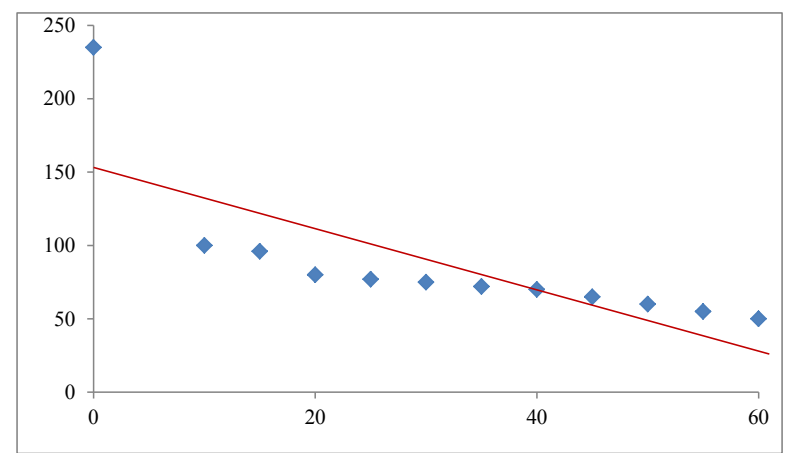

Fig. 7. Chart of the regression equation for a change in the amount of dry residue after roasting in the composition of wastewater $(\hat{y}=-2.0508 x+152.2959)$

Fisher's criterion was $F_{\text {fakt }} \approx 13.6892 ; F_{\text {tabl }} \approx 4.9646, \alpha=$ $=0.05$; Student's $t$-statistics $t_{\text {tabl }} \approx 2.2282, t_{a} \approx-3.6999, \alpha=0.05$. The Darbin-Watson criterion was $d \approx 1.2291$.
5. 2. Determining nitrogen, phosphorus, calcium, potassium, and sodium in wastewater

Changes in the content of total nitrogen under the influence of plasmochemical activation are shown in Fig. 8.

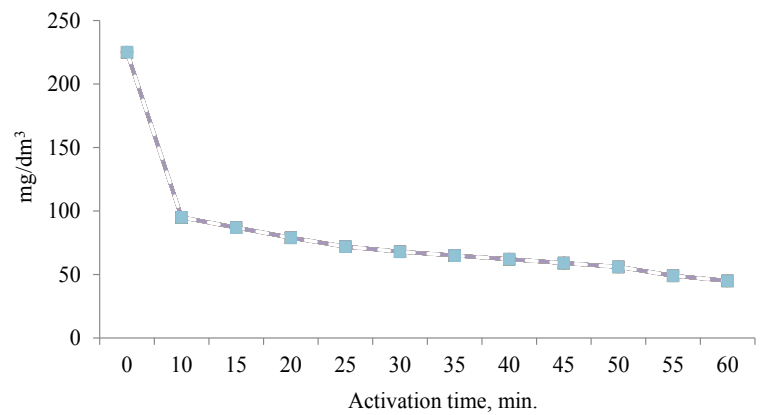

Fig. 8. The content of total nitrogen in the composition of malt production wastewater when using the plasmochemical activation of technological solutions

The analysis of our results has made it possible to build a linear regression equation shown in Fig. 9.

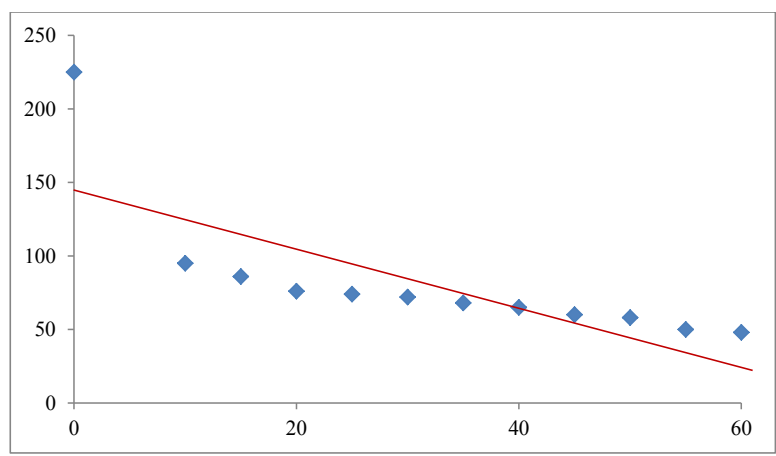

Fig. 9. Chart of the regression equation for a change in the amount of total nitrogen in the composition of wastewater $(\hat{y}=-1.9583 x+142.9941)$

Fisher's criterion was $F_{\text {fakt }} \approx 14.2697 ; F_{\text {tabl }} \approx 4.9646, \alpha=$ $=0.05$; Student's $t$-statistics $t_{\text {tabl }} \approx 2.2282, t_{a} \approx-3.7775$, $\alpha=0.05$. The Darbin-Watson criterion was $d \approx 1.1977$.

The content of phosphorus, potassium, and calcium was also investigated. The integrated results are shown in Fig. 10.

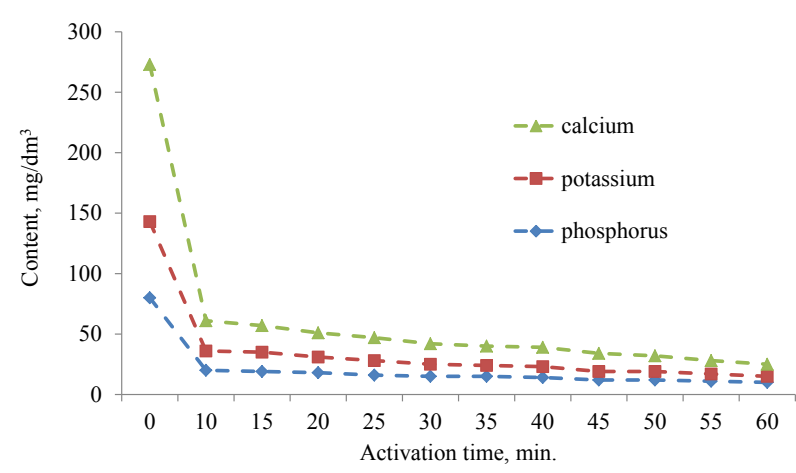

Fig. 10. The content of phosphorus, potassium, and calcium in the composition of malt production wastewater when using the plasmochemical activation of technological solutions

Analyzing the results that are shown in Fig. 10, one should note the stable dynamics towards a decrease in the 
amount of foreign chemical elements (phosphorus, potassium, calcium) at the plasmochemical activation of wastewater. Sodium content was also investigated, its amount at the activation of aqueous solutions decreased by 6 times.

5. 3. Determining oxidation, biochemical oxygen consumption, and $\mathrm{pH}$ of wastewater

We studied the oxidation of wastewater and biochemical oxygen consumption; the results are shown in Fig. 11.

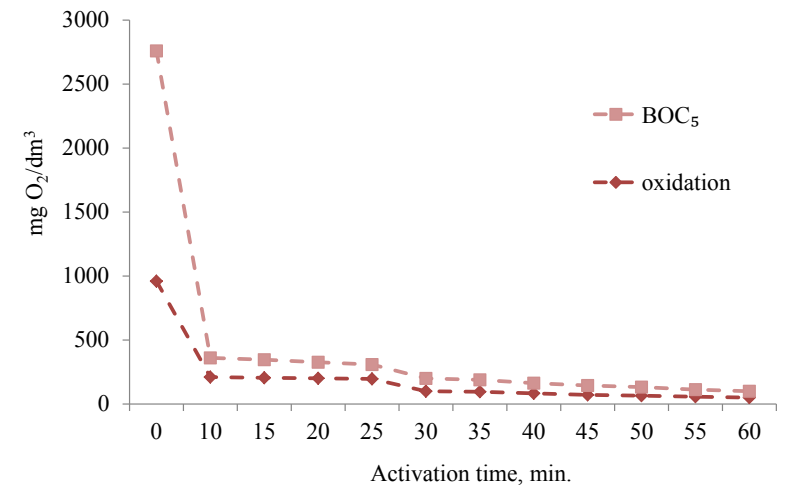

Fig. 11. The oxidation and the biochemical oxygen consumption $\left(\mathrm{BOC}_{5}\right)$ of malt production wastewater when using the plasmochemical activation of technological solutions

The change in indicators observed in Fig. 11 indicates a reduction in microbiological wastewater contamination. The treatment of the obtained data allowed us to build a linear regression equation shown in Fig. 12.

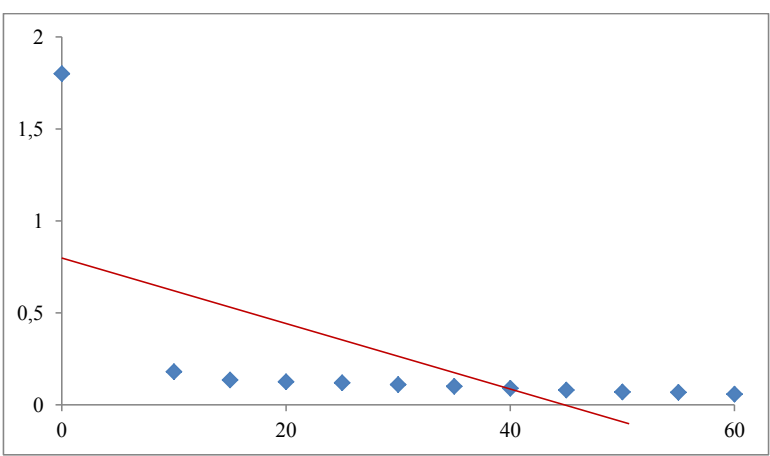

Fig. 12. Chart of the regression equation for a change in $\mathrm{BOC}_{5}$ in wastewater $(\hat{y}=-15.5609 x+736.497)$

Fisher's criterion was $F_{\text {fakt }} \approx 5.3964 ; F_{\text {tabl }} \approx 4.9646, \alpha=$ $=0.05$; Student's $t$-statistics $t_{\text {tab }} \approx 2.2282, t_{a} \approx-2.323, \alpha=0.05$. The Darbin-Watson criterion was $d \approx 1.3116$.

The analysis of wastewater $\mathrm{pH}$ was carried out. At the plasmochemical activation of wastewater, the indicator varies from 6.5 to 10.0 depending on the treatment time, that is, the acidic environment is alkalized without the use of chemical reagents.

\subsection{Studying the microbiological contamination of} wastewater

Microbiological examination of wastewater was also conducted (by seeding on nourishing environments and by registering the colonies using a microscope) for the presence of phytopathogenic microflora, which comes from grains.
Table 4

Effect of plasmochemical activation of wastewater on phytopathogenic microflora, number of microorganisms in $1 \mathrm{ml}$ of wastewater

\begin{tabular}{|c|c|c|c|c|c|c|c|c|c|c|c|c|}
\hline $\begin{array}{c}\text { Phytopatho- } \\
\text { genic micro- } \\
\text { flora }\end{array}$ & \multirow{8}{*}{ Control } & \multicolumn{10}{|c|}{ Duration of wastewater plasmochemical } \\
\cline { 3 - 17 } & & 10 & 15 & 20 & 25 & 30 & 35 & 40 & 45 & 50 & 55 & 60 \\
\hline Aspergillus & 258 & 231 & 175 & 136 & 94 & 67 & 48 & 25 & 7 & 0 & 0 & 0 \\
\hline Alternaria & 79 & 61 & 54 & 47 & 34 & 21 & 13 & 8 & 3 & 0 & 0 & 0 \\
\hline Penicillium & 56 & 50 & 43 & 39 & 31 & 22 & 16 & 7 & 2 & 0 & 0 & 0 \\
\hline Fusarium & 16 & 14 & 11 & 8 & 6 & 4 & 3 & 3 & 1 & 0 & 0 & 0 \\
\hline Mucor & 75 & 71 & 65 & 57 & 49 & 41 & 34 & 27 & 16 & 8 & 2 & 0 \\
\hline
\end{tabular}

Analyzing data from Table. 4, one should note a decrease in the number of microorganisms (phytopathogenic microflora) in wastewater during its plasmochemical activation, and, at prolonged activation (50-60 minutes), microorganisms were not detected at all. When activating over $60 \mathrm{~min}$, even mold microflora (Mucor) was completely destroyed.

Based on the above data, it should be noted that the optimal time of the plasmochemical activation of wastewater was a time of 60 minutes, at which the indicators of the contamination (chemical and microbiological) of wastewater accepted minimal values.

6. Discussion of results of studying the intensive technology for obtaining a biologically-active component of food products

The use of a low-temperature plasma discharge makes it possible to approach the task of drinking and wastewater treatment in a comprehensive way. Thus, when using this method in aqueous solutions that are treated, there are processes that lead to the destruction of organic compounds contained in them, including surface-active substances and halogen-containing organic compounds, or bacterial contaminants. The ions of heavy metals and radionuclides, present in the treated water, are transferred to insoluble compounds, which are then aggregated, adsorbed on the solid suspended particles, present in water, and can be subsequently removed at the filtration stage.

The indicators of malt production wastewater were investigated. Pollution after the activation decreased as follows: dry residue - by 65-95\% (Fig. 2); the content of suspended substances - by 33-66\% (Fig. 4); residue after roasting by $58-79 \%$ (Fig. 6 ) ; total nitrogen - by $58-80 \%$ (Fig. 8 ); $\mathrm{P}_{2} \mathrm{O}_{5}$ (phosphorus) - by $75-88 \%, \mathrm{~K}_{2} \mathrm{O}-$ by $75-92 \%$ (potassium), $\mathrm{CaO}$ (calcium) - by $81-92 \%$ (Fig. 10); $\mathrm{Na}_{2} \mathrm{O}-$ by $67-83 \%$; $\mathrm{Cl}^{-}$- not detected; oxidation - by $78-95 \%$, BOC $_{5}$ (biochemical oxygen consumption) - by $92-97 \%$ (Fig. 11); $\mathrm{pH}$ became alkaline. Activation time influenced the quality of purification (Fig. 3, 5, 7, 9, 12). We observed the following: the longer the activation of wastewater, the lower the amount of pollutants was detected. During plasmochemical activation, there is a disruption of the stability of the solution. In addition, most elements and chemical compounds enter specific reactions and are deposited. Such trends in the changes in indicators after the activation indicate the prospects for cleaning technological solutions using the plasmochemical activation.

It should be noted that solutions in the process of treating them with a contact uneven plasma acquire pronounced bactericide properties that are prolonged in character [23]. 
Since wastewater after the plasmochemical treatment is planned to be further used, its microbiological contamination is important. One possible mechanism for the effect of plasmochemical activation on the wastewater pathogenic microflora is a change in the outer layers of the phytopathogenic microorganisms' cell, which makes the receptors available for reactogenic enzymes, such as lysozyme. Free radicals form a breach in the cell wall, which leads to the loss of selective permeability. Hydrogen peroxide, which is part of activated water, causes microorganisms to destroy the surface structures and internal membranes. The integrity of the cytoplasmic membrane disrupts the work of a series of membrane-related enzymes, such as dehydrogenase, and reduces the effectiveness of DNA reparation systems [24]. The bactericide activity of hydrogen peroxide and activated solutions is primarily associated with their high oxidative capacity, as well as the action of toxic products that emerge at the peroxide oxidation of lipids. Peroxide oxidation affects the ribosome proteins, causing them to break down. The destruction of the membrane structure is facilitated by the formed ultra-permeable compounds [25]. The effect of hydrogen peroxide or activated water causes local destruction of the whole cell wall and impaired permeability of bacterial cells in the first minutes of contact. The result is the ability to decontaminate wastewater through its plasmochemical treatment. Thus, as a result of wastewater treatment over $60 \mathrm{~min}$, the phytopathogenic microflora, which was present in the control samples, dies completely (Table 4). That is, the resulting aqueous solutions are fully suitable for further technological use.

The plasmochemically activated wastewater can be used again for soaking the grain material (first soaking), as evidenced by the composition and microbiological state of the treated wastewater (Table 4). In the proposed technology, the main element of the process is a plasmochemical installation that produces activated solutions in the amount of $1.5-2 \mathrm{~m}^{3}$ per hour. It is located on the same premises that host a technological line, connects to a washing vat and malt-growing boxes. The spent liquid is settled, filtered, and sent for re-treatment into a plasmochemical plant for cleaning and disinfection purposes.

Malt production wastewater tends to oxygenate, so it is often alkalized; given the plasmochemical activation, this is excluded because wastewater after the activation has an alkalinity of $8-10 \mathrm{pH}$, which prevents oxidation. Thus, when using the solutions of chemical compounds as a liquid for grain soaking, they enter the wastewater, and this makes their treatment more difficult. When using a plasmochemical activation, a significant part of chemical compounds (metals, salts, etc.) is deposited, which makes it possible to remove from the solution pollutants of different chemical nature. Applying such a universal wastewater treatment component at an enterprise is a positive result of effective environmental use.

A given scheme makes it possible to reduce the general water needs for soaking (by its reuse after purification by activation) by more than $40-70 \%$, depending on the features of malting process technology. Therefore, one can argue about the prospects of using the plasmochemical activation of aqueous solutions in the process of ecologization of the malt industry.

The volume of wastewater at malt enterprises is not stable and depends on the volume of grain processing. Processing 1 cubic meter of wastewater at a maximum activation time is USD 1. Dimensions of the industrial installation make it possible to locate in a malting plant: they are 2.5 by $1.5 \mathrm{~m}$. It should also be noted that the main purpose of this equipment is the activation of water for the intensification of malting, and its use in the process of treating malt production wastewater would make the process of activation universal.

Our study may have limitations relating to specific impurities in wastewater, such as dioxin impurities. Their behavior under the influence of plasmochemical activation has not yet been investigated.

This study could be advanced by implementing the plasmochemical processes directly at malt enterprises. Thus, for their implementation, namely for the plasmochemical treatment of technological solutions, an industrial device was designed, which provides for a wide range of technological processes in various industries using a contact uneven low-temperature plasma. The Open Joint Stock Company "Dnipro Machine-Building Plant", Dnipro, Ukraine, launched the production of portable laboratory installations for conducting research directly under laboratory conditions at various industrial enterprises, as well as experimental and industrial plasmochemical installations with a capacity of 0.5 and $2.0 \mathrm{~m}^{3}$ /hour of treated liquid environments directly at industrial enterprises. At present, work is underway to launch mass production of plasmochemical industrial installations for their further widespread use in the industry.

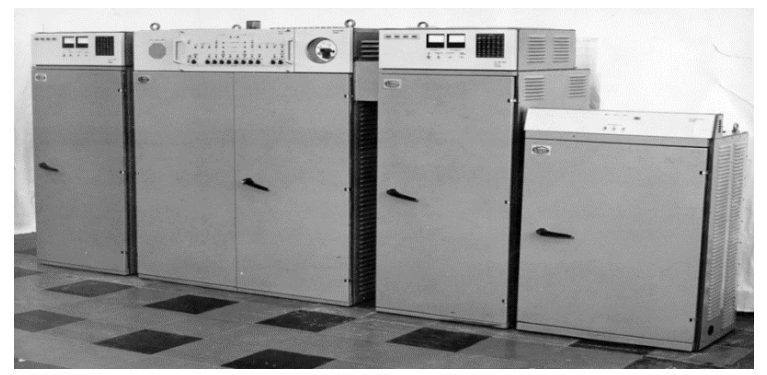

Fig. 13. Experimental and industrial installation with a capacity of $1.5-2.0 \mathrm{~m}^{3} / \mathrm{h}$ of treated liquid environments

It is recommended to implement the results of our study into industrial malt production, which could reduce the consumption of water and improve the quality of wastewater, which significantly pollutes reservoirs. An important aspect of industrial production will also be the improvement of wastewater indicators, which would improve the quality of technological solutions in their reuse. The proposed technology of purification of technological solutions acquires special practical value in terms of the chemical purity of technological process, namely, in the absence of need for additional application of chemical reagents of an inorganic and organic origin at various stages of malt production.

\section{Conclusions}

1. We have performed the plasmochemical treatment of wastewater from malt production to determine the degree of its chemical and microbiological purification. The activation time was 10, 15, 20, 25, 30, 35, 40, 45, 50, 55, $60 \mathrm{~min}$.

2 . The indicators of malt production wastewater were investigated. Its contamination decreased after the plasmochemical activation as follows: dry residue - by $65-95 \%$; the content of suspended substances - by $33-66 \%$; residue after roasting - by 58-79 \%; total nitrogen - by 58-80\%; $\mathrm{P}_{2} \mathrm{O}_{5}-$ by $75-88 \% ; \mathrm{K}_{2} \mathrm{O}$ - by $75-92 \%$ (potassium); $\mathrm{CaO}$ (cal- 
cium) - by $81-92 \% ; \mathrm{Na}_{2} \mathrm{O}$ - by $67-83 \% ; \mathrm{Cl}^{-}-$not detected; oxidation - by $78-95 \%$; $\mathrm{BOC}_{5}$ (biochemical oxygen consumption) - by $92-97 \%$; $\mathrm{pH}$ became alkaline. The change in indicators varied depending on plasmochemical processing modes. The rational regime of the plasmochemical activation is 60 minutes; at such treatment, the purified wastewater has a minimum level of contamination. Consequently, it will be advisable to reuse it to ensure technological processes in malt production.
3. The effect of plasmochemical treatment on the phytopathogenic microflora in wastewater was investigated; the phytopathogenic microflora Aspergillus, Alternaria, Penicillium, Fusarium in wastewater was completely destroyed under processing modes of 50-60 minutes. At the plasmochemical treatment over 60 minutes, even the persistent mold of the Mucor microflora dies. Therefore, such plasmochemically treated wastewater can be reused in the malting processes without additional decontamination.

\section{References}

1. Deineko, L. V., Sheludko, E. I. (2006). Ekoloho-ekonomichni problemy realizatsiyi prodovolchoho potentsialu Ukrainy u konteksti rozshyrennia YeS i formuvannia YeEP. Yevropeiski intehratsiyni protsesy i transkordonne spivrobitnytstvo. Tezy dop. III Mizh nar. nauk.-prakt. konf. studentiv, aspirantiv i molodykh naukovtsiv. Vol. 2. Lutsk, 188-193.

2. Deineko, L. V., Khlobystov, Ye. V., Sychevskyi, M. P. (2007). Ekolohichni ta sotsialno-ekonomichni problemy zabezpechennia yakosti ta konkurentozdatnosti natsionalnoi kharchovoi promyslovosti: dyskusiynyi pohliad. Hospodarskyi mekhanizm ekolohichno zbalansovanoho rozvytku: Zbirnyk tez dopovidei Vseukrainskoi nauk. konf. Sumy: Vyd-vo SumDU, 30-39.

3. Pivovarov, O., Kovaliova, O. (2019). Features of grain germination with the use of aqueous solutions of fruit acids. Food Science and Technology, 13 (1). doi: https://doi.org/10.15673/fst.v13i1.1334

4. Pivovarov, O., Kovaliova, O., Khromenko, T., Shuliakevych, Z. (2017). Features of obtaining malt with use of aqueous solutions of organic acids. Food Science and Technology, 11 (4). doi: https://doi.org/10.15673/fst.v11i4.728

5. Lewis, M. J., Young, T. W. (1995). Malting technology: malt, specialized malts and non-malt adjuncts. Brewing, 48-70. doi: https:// doi.org/10.1007/978-1-4615-1801-3_4

6. Narziß, L., Back, W., Gastl, M., Zarnkow, M. (2017). Abriss der Bierbrauerei. John Wiley \& Sons. doi: https://doi.org/ $10.1002 / 9783527812820$

7. Vanginkel, S., Oh, S., Logan, B. (2005). Biohydrogen gas production from food processing and domestic wastewaters. International Journal of Hydrogen Energy, 30 (15), 1535-1542. doi: https://doi.org/10.1016/j.ijhydene.2004.09.017

8. Keiser, D. A., Kling, C. L., Shapiro, J. S. (2018). The low but uncertain measured benefits of US water quality policy. Proceedings of the National Academy of Sciences, 116 (12), 5262-5269. doi: https://doi.org/10.1073/pnas.1802870115

9. Heidt, O. P. (2010). Rozvytok ekobezpechnykh tekhnolohiy v silskohospodarskomu vyrobnytstvi. Zb. nauk. prats Tavriyskoho derzhavnoho ahrotekhnichnoho universytetu. Seriya: ekonomichni nauky, 3 (11), 308-315.

10. Galech'yan, N., Guseva, Yu. (2009). Ekoprodukty v sovremennom mire. Prodovolcha industriya APK, 2, 14-17.

11. Pivovarov, O. A., Tyshchenko, A. P., Kovalova, O. S. (2010). Ekolohichni aspekty rozvytku ta udoskonalennia vyrobnytstv solodovoi haluzi. Zbirnyk statei uchasnykiv VI Vseukrainskoi naukovo-praktychnoi konferentsiyi «Okhorona navkolyshnoho seredovyshcha promyslovykh rehioniv yak umova staloho rozvytku Ukrainy». Zaporizhzhia: Vydavnytstvo TOV «Finvei», 248-252.

12. Rai, M., Yadav, A., Gade, A. (2009). Silver nanoparticles as a new generation of antimicrobials. Biotechnology Advances, 27 (1), 76-83. doi: https://doi.org/10.1016/j.biotechadv.2008.09.002

13. Krutyakov, Y. A., Kudrinskiy, A. A., Olenin, A. Y., Lisichkin, G. V. (2008). Synthesis and properties of silver nanoparticles: advances and prospects. Russian Chemical Reviews, 77 (3), 233-257. doi: https://doi.org/10.1070/rc2008v077n03abeh003751

14. Abou El-Nour, K. M. M., Eftaiha, A., Al-Warthan, A., Ammar, R. A. A. (2010). Synthesis and applications of silver nanoparticles. Arabian Journal of Chemistry, 3 (3), 135-140. doi: https://doi.org/10.1016/j.arabjc.2010.04.008

15. Qin, Y., Ji, X., Jing, J., Liu, H., Wu, H., Yang, W. (2010). Size control over spherical silver nanoparticles by ascorbic acid reduction. Colloids and Surfaces A: Physicochemical and Engineering Aspects, 372 (1-3), 172-176. doi: https://doi.org/10.1016/j.colsurfa.2010.10.013

16. Goncharuk, V. V. (2014). Water Clusters. Drinking Water, 51-103. doi: https://doi.org/10.1007/978-3-319-04334-0_3

17. Bockstedte, M., Kley, A., Neugebauer, J., Scheffler, M. (1997). Density-functional theory calculations for poly-atomic systems: electronic structure, static and elastic properties and ab initio molecular dynamics. Computer Physics Communications, 107 (1-3), 187-222. doi: https://doi.org/10.1016/s0010-4655(97)00117-3

18. Zaharov, S. D., Mosyagina, I. V. (2011). Klasternaya struktura vody (obzor). Moscow, 24.

19. Ignatov, I., Mosin, O. V. (2003). Isotopic Composition of Water and its Temperature in Modeling of Primordial Hydrosphere Experiments. Science Review, 1, 17-27.

20. Maheshwary, S., Patel, N., Sathyamurthy, N., Kulkarni, A. D., Gadre, S. R. (2001). Structure and Stability of Water Clusters (H2O) n,n=8-20: An Ab Initio Investigation. The Journal of Physical Chemistry A, 105 (46), 10525-10537. doi: https://doi.org/10.1021/ jp013141b

21. Larson, M. A., Garside, J. (1986). Solute clustering in supersaturated solutions. Chemical Engineering Science, 41 (5), $1285-1289$. doi: https://doi.org/10.1016/0009-2509(86)87101-9

22. Chaplin, M. F. (2000). A proposal for the structuring of water. Biophysical Chemistry, 83 (3), 211-221. doi: https://doi.org/10.1016/ s0301-4622(99)00142-8

23. Kojtari, A., Ercan, U. K., Smith, J., Friedman, G., Sensenig, R. B. et. al. (2013). Chemistry for Antimicrobial Properties of Water Treated With Non-Equilibrium Plasma. Journal of Nanomedicine \& Biotherapeutic Discovery, 04 (01). doi: https://doi.org/ 10.4172/2155-983x.1000120 
24. Chen, T.-P., Liang, J., Su, T.-L. (2018). Plasma-activated water: antibacterial activity and artifacts? Environmental Science and Pollution Research, 25 (27), 26699-26706. doi: https://doi.org/10.1007/s11356-017-9169-0

25. Oehmigen, K., Hähnel, M., Brandenburg, R., Wilke, C., Weltmann, K.-D., von Woedtke, T. (2010). The Role of Acidification for Antimicrobial Activity of Atmospheric Pressure Plasma in Liquids. Plasma Processes and Polymers, 7 (3-4), 250-257. doi: https:// doi.org/10.1002/ppap.200900077

Radioactive contamination of the aboveground phytomass of marsh Labrador tea (Ledum palustre L.) in different periods after the Chernobyl accident was studied. Marsh Labrador tea is widely used in official and folk medicine. The studied species grows in over-moistened pine (less mixed) forests and open oligotrophic and mesotrophic marshes. It was found that in the first four years since the beginning of observations (1991), the magnitude of the specific activity of ${ }^{137} \mathrm{Cs}$ in above-ground vegetative phytomass of marsh Labrador tea, depending on a permanent sample area (PSA), decreased by 1.2-1.4 times. After 10 years, it decreased by 1.6-1.7 times, after 16 years by 1.9-2.1 times, after 21 years by 2.73.1 times, and after 27 years by 3.1-6.5 times. An increase in the magnitude of transitions factors was also observed on all PSA over time. Thus, the minimal increase within 1991-2018 was recorded in PSA 11 - by 1.2 times and on PSA 13 - by 1.4 times. The maximum decrease in the magnitude of transition coefficient was observed in PSA 16 - by 2.7 times, in PSA 15 - by 3.0 times, and in PSA 18 - by 2.0 times. It was found that marsh Labrador tea belongs to the group of plants that are characterized by the high content of ${ }^{137} \mathrm{Cs}$ in the above-ground vegetative phytomass. Within the observation period (1991-2018), this content significantly exceeds the admissible levels of radionuclide content in plant medicinal raw materials that are used for manufacturing medical preparations. In the PSA with maximum magnitudes of soil contamination density $\left(400.5 \pm 50.73 \mathrm{kBk} \cdot \mathrm{m}^{-2}\right)$ this excess made up 158.4 times in 1991, and 33.7 times $\left(166.9 \pm 23.56 \mathrm{kBk} \cdot \mathrm{m}^{-2}\right)$ in 2018. For 27 years of observations, there has been a decrease in the density of radioactive soil contamination by 2.12.7 times, which is due to radionuclide decomposition, its vertical migration in the soil, and towards the components of forest ecosystems

Keywords: specific activity of ${ }^{137} \mathrm{Cs}$, radioactive contamination, migration of radionuclides, phytomass, forest ecosystems
UDC 546.36.027*137:582.912.42(477.1-924.82/.84):504.054/.5

DOI: $10.15587 / 1729-4061.2020 .211933$

COMPARING THE RADIOACTIVE CONTAMINATION OF MARSH LABRADOR TEA (LEDUM PALUSTRE L.) OVER DIFFERENT PERIODS SINCE CHERNOBYL ACCIDENT

\author{
V. Krasnov \\ Doctor of Agricultural Sciences, Professor* \\ O. Orlov \\ $\mathrm{PhD}$, Senior Researcher** \\ O. Zhuk ovs k y i \\ Researcher** \\ M. Korbut \\ $\mathrm{PhD}$, Associate Professor* \\ I. Dav y d ova \\ PhD, Associate Professor* \\ V. Me I n y k \\ Assistant* \\ E-mail: melnyk_vika91@ukr.net \\ O. Z borovska \\ $\mathrm{PhD}$, Senior Researcher** \\ *Department of Ecology \\ Zhytomyr Polytechnic State University \\ Chudnivska str., 103, Zhytomyr, Ukraine, 10005 \\ ** Laboratory of Radiation Ecology of the Forest
}

Poliskiy Branch of Ukrainian Research Institute of Forestry and Agro-Forest Melioration named after G. M. Vysotsky Neskorenykh str., 2, Dovzhyk vil., Zhytomyr reg., Ukraine, 10004

\section{Introduction}

Marsh Labrador tea (Ledum palustre L.) is a fairly common plant of over-moistened pine (less often mixed) forests, open oligotrophic and mesotrophic sphagnum swamps [1]. The main part of the marsh Labrador tea areal is common in Polissya on the territories that most suffered from radioactive contamination (mainly with ${ }^{137} \mathrm{Cs}$ ) as a result of the accident at the Chernobyl nuclear plant.

It is known that as a result of the Chernobyl accident, forests suffered from significant radioactive contamination, which caused a revision of existing ideas and many regulato- 